\title{
Curative Surgery
}

National Cancer Institute

\section{Source}

National Cancer Institute. Curative Surgery. NCI Thesaurus. Code C38047.

Surgery which cures disease. 